Annals of International Medical and Dental Research

E-ISSN: 2395-2822 | P-ISSN: 2395-2814

Vol-8, Issue-1 | January-February 2022

DOI: $10.53339 /$ aimdr.2022.8.1.32

Page no- 243-252 | Section- Research Article (Urology)

\title{
Evaluation of Epididymo-Orchtis-A Study of 100 Cases
}

\section{Mohammad Kamrul Islam ${ }^{1 *}$, Rehena Nasreen ${ }^{2}$, Sumon Kumar Sen ${ }^{3}$, Md. Mahamudul Hasan ${ }^{4}$}

1Rasident, Department of Urology, Bangabandhu Sheikh Mujib Medical University, Dhaka, Bangladesh.

Email: medicheque@gmail.com

Orcid ID: 0000-0003-2879-4570

${ }^{2}$ Medical Officer, department of obstetrics and gynecology, Dhaka Medical College Hospital, Dhaka, Bangladesh.

Email: rehenanasrin82@gmail.com

Orcid ID: 0000-0001-9612-5809

${ }^{3}$ Consultant, Department of Surgery, Central

Police Hospital, Dhaka, Bangladesh.

Email: Drsksen415@gmail.com

Orcid ID: 0000-0003-3480-1300

${ }^{4}$ Junior Consultant, Department of Surgery, Bangabandhu Sheikh Mujib Medical University, Dhaka, Bangladesh.

Email: drmhpannu@gmail.com

Orcid ID: 0000-0002-8915-3243.

*Corresponding author

\section{Abstract}

Background: Acute epididymo-orchitis is a common clinical problem in urological practice. It is not an uncommon disease in our country to cause work loss particularly in active group of people. Aim of the study: The aim of this study was to see the predisposing factors involved, aetiopathology and progression of disease process. Methods: This prospective study was conducted in department of surgery, Kumudini Women's Medical College Hospital, Tangail from April 2008 to March 2009. Hundred patients of inflammation of epididymis and testis were included in this study. Results: Out of 100 patients, majority $(48 \%)$ were in monogamous relationship. All patients (100\%) had scrotal pain, 22\% had scrotal swelling, 59\% had fever, 32\% had dysuria and $11 \%$ had urethral discharge. All patients presented with tenderness of the testis and epididymis and $82 \%$ cases had both epididymal and testicular swelling. Thirty two percent cases had urinary tract infection, trauma and promiscuous sexual contact were associated with the disease in $2 \%$ and $18 \%$ cases, respectively. History of masturbation was noted in $18 \%$ cases. By urine routine microscopy $28 \%$ had pus cell and $03 \%$ had RBC in urine, 16 cases were positive in urine culture, among $15 \%$ were E.coll and $01 \%$ were found Klebsiela. Forty patients were tested Chlamydial CFT and 16(40\%) were found positive, out of 12 Filarial CFT tested 01(8.33 \%) was found positive, Gram staining of urethral discharge revealed Neisseria gonorhhoae in $02(18.18 \%)$ cases. In maximum cases no actiological factor was found. Majority cases under 35 years were infected with Chlamydia and patients older than 35 years were mostly infected with E.coli. Conclusion: This study reflects that maximum of our study patients report to hospital nearly at right time with relatively better health status and outcome of available treatment facilities are satisfactory.
Received: 22 September 2021

Revised: 12 November 2021

Accepted: 23 November 2021

Published: 22 December 2021 exploration. As it is a vital organ and also relates with patients psychological aspect a non-operative approach is desirable both for the patient and physician. Among the causes of acute scrotum, epididymo-orchitis ranks in the top. Epididymitis and subsequent orchitis is a clinical condition resulting from inflammation 
Annals of International Medical and Dental Research

E-ISSN: 2395-2822 | P-ISSN: 2395-2814

Vol-8, Issue-1 | January-February 2022

DOI: $10.53339 /$ aimdr.2022.8.1.32

Page no- 243-252 | Section- Research Article (Urology)

of epididymis and testis are commonly related to infection in the urinary tract (cystitis, urethritis, prostatitis) which presumably reach the epididymis and the testis through either the vas difference or lymphatics of the spermatic cord.[1] Abscess formation, testicular infarction, development of chronic pain, swelling and infertility are complications of epididymo-orchitis.[2] Epididymitis is a common form of scrotal swelling, occurring in a wide age range but typically increasing in frequency with age. [3] The cause of epididymoorchitis varies with age of the patient. In young males, the sexually transmitted pathogens such as Chlamydia Trachomatis and Neisseria Gonorrhea are the most common pathogens. Both are associated with arthritis. Epididymoorchitis is less common in older males but when it does occur, it is most often due to infection secondary to urinary tract obstruction and instrumentation. [4] Although epididymoorchitis is uncommon in children, is usually associated with congenital genitouninary tract abnormality and infection with negative rods. In all age groups epididymitis may be related to a systemic infectious or inflammatory disease, e.g. tuberculosis, brucella, sarcoid and cryptococcus. These disorders usually cause chronic rather than acute epididymitis.[5] An attempt has been made in this small series of hundred patient to identify the problems related to epididymo-orchitis in our patients. It is an important disability causing loss of work of active group people. There is always a fear of mutilation and many patients do not seek medical advice until the condition becomes chronic or advanced. Though the small study of hundred cases will represent a picture of the disease but to make any firm conclusion about the disease in our country, needs a more elaborate study and analysis.

\section{Objectives}

1. To see the predisposing factors involved.

2. To observe the progression of disease process.

3. To study clinical presentation and management of the disease.

4. To compare the outcome with other studies done in home and abroad

\section{MATERIAL AND METHODS}

This prospective study was conducted in department of surgery, Kumudini Women's Medical College Hospital, Tangail from April 2008 to March 2009. Hundred patients of inflammation of epididymis and testis were included in this study. A questionnaire has been formulated, data collection done by principle author. Patients were investigated, diagnosed and received appropriate therapy. The departmental records were reviewed subsequently and relevant notes obtained. Data was processed and analyzed using SPSS24 (Statistical Package for Social Sciences) software. Data processed on categorical scale was presented as frequency and percentage. While the data presented on continuous scale it was presented as mean standard deviation and analyzed with the help of student $T$ test. The merged data was then presented in the table and chart.

\section{Inclusion criteria:}

1. All male patient with acute scrotum.

2. Cooperative patient.

3. Patient who has not treated outside the hospital earlier for same reason 
Annals of International Medical and Dental Research

E-ISSN: 2395-2822 | P-ISSN: 2395-2814

Vol-8, Issue-1 | January-February 2022

DOI: $10.53339 /$ aimdr.2022.8.1.32

Page no- 243-252 | Section- Research Article (Urology)

4. All hospitalized patient and willing for follow up.

\section{Exclusion criteria:}

1. Noncooperative patient

2. Patient with testicular torsion, testicular tumor diagnosed earlier.

3. Already diagnosed as chronic epididymoorchilis

\section{RESULTS}

[Table 1] shows age group distribution of the study population, minimum age was 15 years and maximum age was 65 years. Majority age incidence was second and third decade. Table 1 also shows majority (53\%) respondent were industrial worker, followed by $22 \%$ were businessman, $17 \%$ were student and $08 \%$ were day labor. [Table 2] shows the various features of clinical presentation. In this study hundred percent of the patients presented with scrotal pain, 22\% patient with total swelling, 59\% with fever, $32 \%$ with dysuria and $11 \%$ with urethral discharge. [Table 3] shows the presenting signs, all patients were presented with tenderness of the testis and epididymis, $82 \%$ cases had both epididymal and testicular swelling, $07 \%$ and $11 \%$ cases had only epididymal and testicular swelling respectively. Among other associated features $2 \%$ were varicocele and $7 \%$ were secondary hydrocele. [Table 4] shows 09\% cases had bilateral involvement, right side had little higher $(49 \%)$ incidence than left side (42\%). [Table 5] shows $32 \%$ had urinary tract infection, $2 \%$ trauma and $18 \%$ promiscuous sexual contact. History of masturbation was noted in $18 \%$ cases. Twelve percent cases had history of previous operation (i.e. operation for hydrocele, inguinal hernia and enlarged prostate), $4 \%$ cases had urethral instrumentation (TURP and urinary catheterization), $6 \%$ cases had mumps and $4 \%$ cases had from prostatism. [Table 6] shows the investigation results of the study population. Leukocytosis was found in $20 \%$ cases, ESR was raised in $18 \%$ cases and $10 \%$ had eosinophilia. In routine urine microscopy pus cell was found in $28 \%$ cases and RBC in 3\% cases. 16 cases had positive urine culture, among them $15 \%$ were E. coli and $1 \%$ was Klebsiella. Forty patients were tested Chlamydial CFT and $16(40 \%)$ were found positive, out of 12 Filarial CFT tested $1(8.33 \%)$ was found positive. Gram staining of urethral discharge revealed Neisseria gonorrhea in $02(18.18 \%)$. All cases were evaluated by Ultrasonogram of scrotum. Evidence of inflammation was found in $100 \%$ cases, suspected tuberculosis (mixed echogenicity/calcification) and hydrocele were found in 5\% and 7\% cases respectively. [Table 7] shows various classes and subclasses of the disease in this series based on history, clinical findings and investigations. In maximum cases no aetiolohical factor was found. [Table 8] shows majority $(55.56 \%)$ cases under 35 years were infected with Chlamydia and patients older than 35 years were mostly infected with E.coli. [Table 9] shows that all the patients $(100 \%)$ received either one or combination of chemotherapeutic agents. Follow-up of the cases in present series was a difficult as maximum patients were industrial workers but the initial cure rate was excellent. Three patients required surgical intervention. One tuberculous epididymo-orchitis patients underwent orchidectomy. [Figure 1] shows majority $48 \%$ were monogamous, $18 \%$ 
Annals of International Medical and Dental Research

E-ISSN: 2395-2822 | P-ISSN: 2395-2814

Vol-8, Issue-1 | January-February 2022

DOI: $10.53339 /$ aimdr.2022.8.1.32

Page no- 243-252 | Section- Research Article (Urology)

promiscuous sexual contact and $34 \%$ were no

sexual contact.

Table 1: Demographic characteristics of the study population $(n=100)$

Characteristics

Age group

Occupation

\begin{tabular}{|c|c|c|}
\hline & Number of patients & Percentage \\
\hline 11-20 years & 14 & 14 \\
\hline 21-30 years & 44 & 44 \\
\hline $31-40$ years & 26 & 26 \\
\hline $41-50$ years & 10 & 10 \\
\hline 51-60 years & 4 & 4 \\
\hline$>60$ years & 2 & 2 \\
\hline Industrial worker & 53 & 53 \\
\hline Businessman & 22 & 22 \\
\hline Student & 17 & 17 \\
\hline Day laborer & 8 & 8 \\
\hline
\end{tabular}

Table 2: Clinical presentation $(n=100)$

Presentation

Pain in the scrotum

Swelling in the scrotum

Fever

Dysuria

Urethral discharge

\begin{tabular}{|l|l|}
\hline Number of patients & Percentage \\
\hline 100 & 100 \\
\hline 82 & 82 \\
\hline 47 & 47 \\
\hline 32 & 32 \\
\hline 11 & 11 \\
\hline
\end{tabular}

Table 3: Physical findings $(\mathrm{n}=100)$

\begin{tabular}{|l|l|l|}
\hline Signs & Number of patients & Percentage \\
\hline Tenderness of the testis and epididymis & 100 & 100 \\
\hline Swelling of both epididymis and testis & 82 & 82 \\
\hline Scrotal oedema & 22 & 22 \\
\hline Associated varicocele & 02 & 02 \\
\hline Associated hydrocele & 07 & 07 \\
\hline Enlarged Prostate & 04 & 04 \\
\hline
\end{tabular}

Table 4: Site of the lesion

\begin{tabular}{|l|l|l|}
\hline Site & Number of patients & Percentage \\
\hline Right & 49 & 49 \\
\hline Left & 42 & 42 \\
\hline Both & 09 & 09 \\
\hline Total & 100 & 100 \\
\hline
\end{tabular}


Annals of International Medical and Dental Research

E-ISSN: 2395-2822 | P-ISSN: 2395-2814

Vol-8, Issue-1 | January-February 2022

DOI: $10.53339 /$ aimdr.2022.8.1.32

Page no- 243-252 | Section- Research Article (Urology)

Table 5: Predisposing factors

\begin{tabular}{|l|l|l|}
\hline Factors & Number of patients & Percentage \\
\hline Urinary tract infection & 32 & 32 \\
\hline Local trauma & 02 & 2 \\
\hline Promiscuous sexual contact & 18 & 18 \\
\hline Masturbation & 18 & 18 \\
\hline Previous operation in urogenital system & 12 & 12 \\
\hline Mumps & 06 & 6 \\
\hline Urethral instrumentation & 04 & 4 \\
\hline Prostatism & 04 & 4 \\
\hline Previous acute episode & 14 & 14 \\
\hline No predisposing factors & 52 & 52 \\
\hline
\end{tabular}

Table 6: Investigations $(\mathrm{n}=100)$

\begin{tabular}{|l|l|l|}
\hline Finding & Number of patients & Percentage \\
\hline Leukocytosis (10000/cmm) & 20 & 20 \\
\hline Raised ESR (>20 mm in 1st hour) & 18 & 18 \\
\hline Eosionophilia & 10 & 10 \\
\hline Pus cell & 28 & 28 \\
\hline RBC & 3 & 3 \\
\hline E. coli & 15 & 15 \\
\hline Klebsiella & 1 & 1 \\
\hline Chlamydial & 16 & 40 \\
\hline Filarial CFT (n=12) & 1 & 8.33 \\
\hline Neisseria gonorhhoae & 2 & 18.18 \\
\hline Evidence of inflammation (Hypoechoic) & 100 & 100 \\
\hline $\begin{array}{l}\text { Suspected } \\
\text { echogenicity/calcification) }\end{array}$ & 5 & 5 \\
\hline Hydrocele & 7 & 7 \\
\hline
\end{tabular}

Table 7: Aetiology $(\mathrm{n}=100)$

\begin{tabular}{|l|l|l|}
\hline Diagnosis & Number of patients & Percentage \\
\hline E. coli & 15 & 15 \\
\hline Klebsiella & 01 & 1 \\
\hline Chlamydia & 16 & 16 \\
\hline Filaria & 01 & 1 \\
\hline Tuberculosis & 05 & 5 \\
\hline Neisseria Gonorrhoae & 02 & 2 \\
\hline Mumps orchitis & 06 & 6 \\
\hline
\end{tabular}


Annals of International Medical and Dental Research

E-ISSN: 2395-2822 | P-ISSN: 2395-2814

Vol-8, Issue-1 | January-February 2022

DOI: $10.53339 /$ aimdr.2022.8.1.32

Page no- 243-252 | Section- Research Article (Urology)

\begin{tabular}{|l|l|l|}
\hline Traumatic & 02 & 2 \\
\hline Idiopathic & 52 & 52 \\
\hline
\end{tabular}

Table 8: Relation between age group with organism $(n=46)$

\begin{tabular}{|l|l|l|l|}
\hline Diagnosis & $\mathbf{3} 3$ years $\mathbf{n = 2 7}(\mathbf{0})$ & $\mathbf{> 3 5}$ years $\mathbf{n = 1 9}(\mathbf{0})$ & Total \\
\hline E.coli & $01(3.70)$ & $\mathbf{1 4}(73.68)$ & 15 \\
\hline Klebsiella & - & $01(5.26)$ & 01 \\
\hline Chlamydia & $\mathbf{1 5 ( 5 5 . 5 6 )}$ & $01(5.26)$ & 16 \\
\hline Filaria & $01(3.70)$ & - & 01 \\
\hline Tuberculosis & $02(7.41)$ & $03(15.79)$ & 05 \\
\hline Neisseria Gonorrhoae & $02(7.41)$ & - & 02 \\
\hline Mumps orthitis & $06(22.22)$ & - & 06 \\
\hline
\end{tabular}

Table 9: Treatment outcome $(n=100)$

\begin{tabular}{|l|l|l|l|}
\hline Treatment & Patients no & Percentage & Remarks \\
\hline Conservative treatment & 97 & 97 & Drainage of abscess in 2 cases \\
\hline Surgical intervention & 3 & 3 & $\begin{array}{l}\text { Orchidectomy in 1 case (Tubercular not } \\
\text { responding to anti TB regimen) }\end{array}$ \\
\hline
\end{tabular}

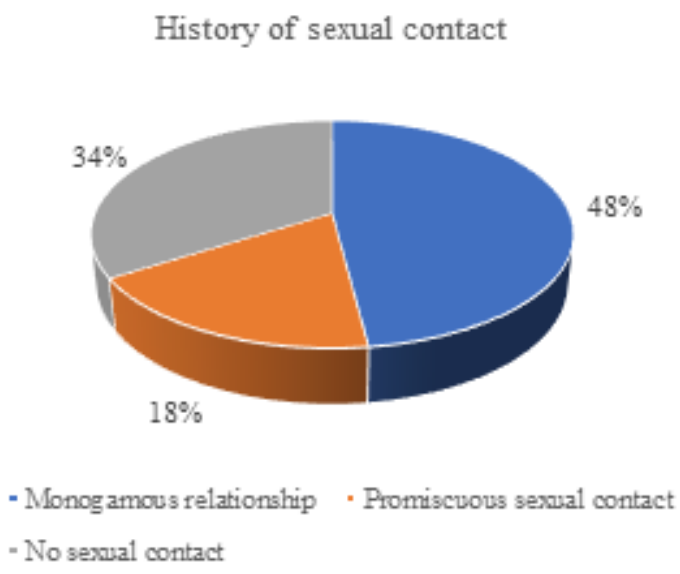

Figure 1: History of sexual contact of the study population

\section{DISCUSSION}

Epidemiological data on epididymo-orchitis is not available in our country so the incidence of epididymo-orchitis in the general population is unknown. Epididymitis/orchitis accounted for 1 in $350(0,29 \%)$ of all consultations and was ranked fifth among genitourinary diagnoses in those aged 18-50 years. [6] To carry out a scientific study in a developing country like us is cumbersome. Economic constraint, mismanagement, lack of effective health education, personal awareness and specially no availability of modern hospital information 
Annals of International Medical and Dental Research

E-ISSN: 2395-2822 | P-ISSN: 2395-2814

Vol-8, Issue-1 | January-February 2022

DOI: 10.53339/aimdr.2022.8.1.32

Page no- 243-252 | Section- Research Article (Urology)

system to bring out a real picture of study is really difficult in spite of all dedicated approach. This study was carried out in such an environment, an attempt has been made at the Kumudini Women's Medical College Hospital, Tangail, to overview few aspects of epididymo-orchitis. In this study, minimum age was 15 years and maximum age 65 years. Majority age incidence was second and third decade. In the study of Lee et al.[7] and with 70 percent in the study of Mittemeyer et al.[8] In a retrospective study in the USA army, the peak incidence was in those 20-29 years old (49\%). [8] In present study showed majority (48\%) were in monogamous relationship, $18 \%$ had promiscuous sexual contact and $34 \%$ were no sexual contact, $32 \%$ cases urinary tract infection, trauma and promiscuous sexual contact were associated with the disease in $2 \%$ and $18 \%$ cases respectively. History of masturbation was noted in $18 \%$ cases. Twelve percent cases had history of previous operation (ie, operation for hydrocele, inguinal hernia and enlarged prostate), $4 \%$ cases had urethral instrumentation (TURP and urinary catheterization), $6 \%$ cases had mumps and $4 \%$ cases had prostatism. Kaver I, et al.[] study showed $71 \%$ cases had sexual exposure, Lee CT et al.[7] study showed $69 \%$ cited prostitutes as the source of sexual contact. Mulcahy FM,[10] studied the prevalence of sexually transmitted infection in 40 men presenting with acute epididymo-architis in Leeds. Chia et al.[11] found that $25(48 \%)$ patients out of 52 had exposure to sexually transmitted disease. These differences with this series are probably our patients are religiously motivated and more prone to trauma due to industrial activity. In a study in the USA army showed similar incidence of trauma $(13.5 \%)$, possibly as a result of activation of infection lying dormant in the epididymis.8 In this study hundred percent of the patients presented with scrotel pain, swelling were present in $22 \%$, Forty seven had fever 32\% had dysuria and $11 \%$ had urethral discharge (09\%) cases had bilateral involvement, right side had little higher (49\%) incidence than left side (42\%). Suankwan U et al.[12] showed the clinical presentations of tuberculous epididymo orchitis included scrotal mass $(80 \%)$, scrotal pain $(44 \%)$, micturition syndrome $(8 \%)$, urethral discharge $(4 \%)$, and scrotal fistula (4\%). One third of the patients had pulmonary tuberculosis. Four patients $(16 \%)$ had underlying human immunodeficiency virus infection. Memish ZA and Venkatesh $S$ study showed all patients complained of swollen painful testicles.[13,14] Other presenting symptoms included undulant fever (96\%), chills (54\%) and arthralgia (23\%). In 2006 Philip J et al.[15] from Liverpool, UK reported clinical findings of 195 males presenting with an acute history of testicular pain and swelling, 25 gave a history of mumps 4-11 days earlier. Three had bilateral orchitis and two needed scrotal exploration to exclude torsion. Scrotal ultrasonography findings varied from increased vascularity to abnormal testicular echo texture. Three had bilateral orchitis and two needed scrotal exploration to exclude torsion. Berger et al.16] noted scrotal oedema in 60 percent cases. because in that series coliform or pseudomonas were isolated in 12 of 16 patients aged $>35$ years. The clinical features in this series are generally in agreement with other series and standard textbook. [6,8,9,11,16,17,18,19,20,21,22,23,24,25] Hundred percent patients presented with local pain. and $82 \%$ presented with scrotal swelling. Acute epididymo orchitis affect the right and left 
Annals of International Medical and Dental Research

E-ISSN: 2395-2822 | P-ISSN: 2395-2814

Vol-8, Issue-1 | January-February 2022

DOI: 10.53339/aimdr.2022.8.1.32

Page no- 243-252 | Section- Research Article (Urology)

sides with equal frequency.[21] In this series, the incidence in left side is little higher: 54.3 percent in the left side and 45.7 percent in the right side. Bilateral involvement is rare: Lee et al.[7] and Mittemeyer et al.[8] noted 7 and 9 percent bilateral cases, respectively, and in this series, 9\% cases had bilateral involvement, right side had little higher $(45 \%)$ incidence than left side $(42 \%)$. In this study leukocytosis was found in $20 \%$ cases, ESR was raised in $18 \%$ and $10 \%$ had eosionophilia, these findings were non-specific. By urine routine microscopy $28 \%$ had pus cell and $03 \%$ had RBC. Sixteen patients had positive urine culture, among them 15\% were E.col and $01 \%$ was Kiebsiella. Forty patients were tested Chlamydial CFT and $16(40 \%)$ were found positive, out of 12 Filarial CFT tested, 01(8.33\%) was found positive. By Gram staining of urethral discharge Neisseria gonorhhoae was found in 02(18.18 \%) cases. All cases were evaluated by Ultrasonogram of scrotum, evidence of inflammation was found in $100 \%$ cases, suspected Tuberculosis (Mixed echogenicity/ calcification) and Hydrocele were found 5\% and $7 \%$ respectively. Current study showed majority $(55.56 \%)$ cases less than 35 years were infected with Chlamydia and patients older than 35 years were mostly infected with E.coli (73.68\%). Mulcahy FM.10] study reported 45\% Chlamydia trachomatis infection in patients aged less than 35 years and only 9\% aged over 35. Escherichia coli was found in $55 \%$ patients aged 35 or over. All the patients (100\%) received either one or combination of chemotherapeutic agents according to European guideline (2012). [26] Follow up of the cases in present series was difficult as maximum patients were industrial workers but the initial cute rate was excellent. Three patients required surgical intervention. One tuberculous epididymo-orchitis patients underwent orchidectomy. According to European guideline for management of epididymo-orchitis empirical therapy should be given to all patients with epididymoorchitis before culture. results are available. For epididymo-orchitis most probably due to any sexually transmitted pathogen ceftriaxone $500 \mathrm{mg}$ intramuscularly single dose plus doxycycline $100 \mathrm{mg}$ by mouth twice daily for 10-14 days if it is most probably due to chlamydia or other non-ganococcal organisms (ie where gonorrhaea is considered unlikely as microscopy is negative for Gram-negative intracellular diplococci and no risk factors for gonorrhoea are identified) tetracycline $100 \mathrm{mg}$ by mouth twice daily for 10-14 days or ofloxacin $200 \mathrm{mg}$ by mouth twice daily for 14 days is to be considered. It is vital that sensitivity testing be undertaken before ofloxacin is given. For epididymo-orchitis most probably due to enteric organisms. ofloxacin $200 \mathrm{mg}$ by mouth twice daily for 14 days or ciprofloxacin $500 \mathrm{mg}$ by mouth twice daily for 10 days. Corticosteroids have been used in the treatment of acute epididymo-orchitis but have not been shown to be of benefit. In those with severe epididymo-orchitis or features suggestive of bacteraemia, inpatient management of fluid and electrolyte balance is required. Intravenous broad spectrum therapy directed towards coliforms and Pseudomonas Aeruginosa should be considered: cefuroxime $1.5 \mathrm{~g}$ two times daily with or without gentamicin for 3-5 days until fever subsides; in those with severe allergy to penicillin, use ciprofloxacin $500 \mathrm{mg}$ twice daily. For epididymo-orchitis of all causes where the patient is allergic to cephalosporins and/or 
Annals of International Medical and Dental Research

E-ISSN: 2395-2822 | P-ISSN: 2395-2814

Vol-8, Issue-1 | January-February 2022

DOI: $10.53339 /$ aimdr.2022.8.1.32

Page no- 243-252 | Section- Research Article (Urology)

tetracyclines: ofloxacin $200 \mathrm{mg}$ by mouth twice daily for 14 days and anti-tubercular drugs were given in suspected TB cases.[26]

\section{Limitations of the Study}

In our study, there was small sample size and for a short period of time. Unfortunately, a good number of patients fail to report to hospital or report lately, because of their ignorance, poverty and lack of adequate healthcare facilities. Laboratory facilities are inadequate and accessible to limited number people. In the present setup, the main areas of lacking to perform a scientific study are recordkeeping, preserving and hospital information system.

\section{REFERENCES}

1. Anthony PP. Robbins' Pathologic Basis of Disease. J Clin Pathol. 1990;43(2):176.

2. Berger RE. Acute epididymitis. Sex Transm Dis. 1981;8(4):286-9.

3. Nickel JC. Chronic epididymitis: a practical approach to understanding and managing a difficult urologic enigma. Rev Urol. 2003;5(4):209-215.

4. Banyra O, Shulyak A. Acute epididymo-orchitis: staging and treatment. Cent European J Urol. 2012;65(3):139-143. doi:10.5173/ceju.2012.03.art8

5. Shah KK, Pritt BS, Alexander MP. Histopathologic review of granulomatous inflammation. J Clin Tuberc Other Mycobact Dis. 2017;7:1-12. doi:10.1016/j.jctube.2017.02.001

6. Krieger JN. Epididymitis, orchitis, and related conditions. Sex Transm Dis. 1984;11(3):173-81. doi: 10.1097/00007435-198407000-00012.

7. Lee CT, Thirumoorthy T, Lim KB, Sng EH. Epidemiology of acute epididymo-orchitis in Singapore. Ann Acad Med Singap. 1989;18(3):320-3.

\section{CONCLUSIONS}

This study was carried out in a narrow spectrum and focused to a low socioeconomic group of people. But it certainly reflects, at least to some extent, the overall situation prevailing in our country though the true incidence is much higher. However, this study reflects that maximum of our study patients report to hospital nearly at right time with relatively better health status and outcome of available treatment facilities are satisfactory We are handicapped in follow-up of patients. Moreover, we are not in a set up to have a scientific approach to a problem and to make a firm conclusion. A further elaborate study is needed to have an epidemiological data on the disease and a multicenter study is essential to evaluate natural history of the disease.

8. Mittemeyer BT, Lennox KW, Borski AA. Epididymitis: a review of 610 cases. J Urol. 1966;95(3):390-2. doi: 10.1016/s0022-5347(17)63468-2.

9. Kaver I, Matzkin H, Braf ZF. Epididymo-orchitis: a retrospective study of 121 patients. J Fam Pract. 1990;30(5):548-52.

10. Mulcahy FM, Bignell CJ, Rajakumar R, Waugh MA, Hetherington JW, Ewing R, Whelan P. Prevalence of chlamydial infection in acute epididymo-orchitis. Genitourin Med. 1987;63(1):16-8. doi: 10.1136/sti.63.1.16.

11. Chia SJ, Ganesan N, Foo KT. An overview of acute scrotal pain. Ann Acad Med Singap. 1995;24(5):7203.

12. Suankwan U, Larbcharoensub N, Viseshsindh W, Wiratkapun C, Chalermsanyakorn P. A clinicopathologic study of tuberculous epididymoorchitis in Thailand. Southeast Asian J Trop Med Public Health. 2012;43(4):951-8.

13. Memish ZA, Venkatesh S. Brucellar epididymoorchitis in Saudi Arabia: a retrospective study of 26 cases and review of the literature. BJU Int. 2001;88(1):72-6. doi: 10.1046/j.1464410x.2001.02243.x. 
Annals of International Medical and Dental Research

E-ISSN: 2395-2822 | P-ISSN: 2395-2814

Vol-8, Issue-1 | January-February 2022

DOI: 10.53339/aimdr.2022.8.1.32

Page no- 243-252 | Section- Research Article (Urology)

14. Memish ZA, Venkatesh S. Brucellar epididymoorchitis in Saudi Arabia: a retrospective study of 26 cases and review of the literature. BJU Int. 2001;88(1):72-6. doi: $\quad$ 10.1046/j.1464410x.2001.02243.x.

15. Philip J, Selvan D, Desmond AD. Mumps orchitis in the non-immune postpubertal male: a resurgent threat to male fertility? BJU Int. 2006;97(1):138-41. doi: 10.1111/j.1464-410X.2006.05902.x.

16. Berger RE, Alexander ER, Harnisch JP, Paulsen CA, Monda GD, Ansell J, Holmes KK. Etiology, manifestations and therapy of acute epididymitis: prospective study of 50 cases. J Urol. 1979;121(6):750-4. doi: 10.1016/s0022-5347(17)569785.

17. Rawat D, Nair D. Extended-spectrum $\beta$-lactamases in Gram Negative Bacteria. J Glob Infect Dis. 2010;2(3):263-274. doi:10.4103/0974-777X.68531

18. Scales BS, Dickson RP, LiPuma JJ, Huffnagle GB. Microbiology, genomics, and clinical significance of the Pseudomonas fluorescens species complex, an unappreciated colonizer of humans. Clin Microbiol Rev. 2014;27(4):927-948. doi:10.1128/CMR.00044-14

19. Mills SEE, Nicolson KP, Smith BH. Chronic pain: a review of its epidemiology and associated factors in population-based studies. $\mathrm{Br} \mathrm{J}$ Anaesth. 2019;123(2):e273-e283. doi:10.1016/j.bja.2019.03.023

20. Todd KH. A Review of Current and Emerging Approaches to Pain Management in the Emergency
Department. Pain Ther. 2017;6(2):193-202. doi:10.1007/s40122-017-0090-5

21. Luzzi GA, O'Brien TS. Acute epididymitis. BJU Int. 2001;87(8):747-55. doi: 10.1046/j.1464410x.2001.02216.x.

22. Shapiro SR, Breschi LC. Acute epididymitis in Vietnam: review of 52 cases. Mil Med. 1973;138(10):643-5.

23. Dale AW, Wilson JD, Forster GE, Daniels D, Brook MG. Management of epididymo-orchitis in Genitourinary Medicine clinics in the United Kingdom's North Thames region 2000. Int J STD AIDS. 2001;12(5):342-5. doi: 10.1258/0956462011923066.

24. Harnisch JP, Berger RE, Alexander ER, Monda G, Holmes KK. Aetiology of acute epididymitis. Lancet. 1977;1(8016):819-21. doi: 10.1016/s01406736(77)92773-8.

25. Wolin LH. On the etiology of epididymitis. J Urol. 1971;105(4):531-3. doi: 10.1016/s0022-5347(17)615672.

26. Street EJ, Justice ED, Kopa Z, Portman MD, Ross JD, Skerlev M, Wilson JD, Patel R. The 2016 European guideline on the management of epididymo-orchitis. Int J STD AIDS. 2017;28(8):744-749. doi: $10.1177 / 0956462417699356$.

Source of Support: Nil, Conflict of Interest: None declared 